\title{
7. The Role of Religion in Society
}

So far, this book has examined how a values-driven dialogue could inspire and broaden the discussion around water and climate change. We have seen how bringing a religious perspective into a traditionally secular arena can help address often overlooked questions around values, worldviews, and existential threat.

In this last chapter we widen our scope and look at the bigger picture, exploring the role of religion in the public sphere and what 'religion as force for good' means. In academic and political circles, many were convinced that modernisation would lead to secularisation and to the decline of religion, the so-called 'secularisation theory'. However, the last decades of the twentieth century provided a massive falsification of this theory. In the last two decades, religion has returned to the public sphere in modern societies. Often this return is associated with violence, like that of 9-II. The return of religion is also associated with refugees and immigrants, and can create a tension between the freedom of religion and the freedom of opinion. Consequently, religion is often a feature of discussions about security in policy circles.

In this chapter, Jan Anthonie Bruijn, President of the Dutch Senate, highlights the Dutch way of respecting freedom of religion and belief in the public sphere. Ernst Hirsch Ballin critically reflects on when to call religion a force for good. Finally, Ecumenical Patriarch Bartholomew accentuates the role religion can play in striving for justice and peace. He stresses the importance of welcoming strangers and refugees into our communities and our hearts. 


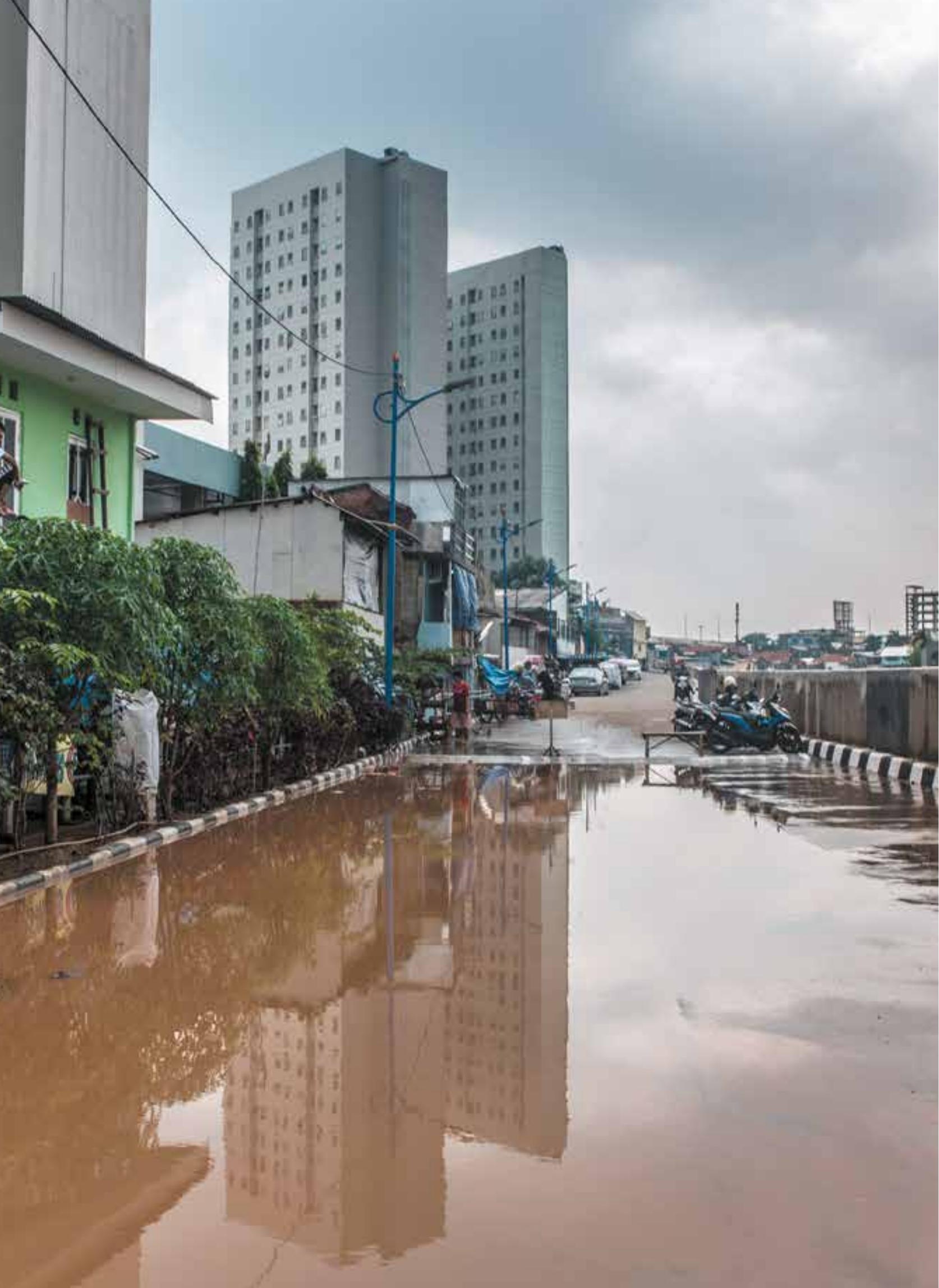




\section{The Netherlands as pluralist society}

PROF. JAN ANTHONIE BRUIJN

PRESIDENT OF THE DUTCH SENATE

We are fond of calling the Senate a chambre de réflexion, a room for thorough consideration of proposed laws and government policies. Our democratic system was built on the fundamental freedoms, starting with the freedom of religion that was explicitly acknowledged as early as 1579 with the Union of Utrecht. This has been part of our peace treaties, together with the care for minorities and the responsibility to protect our society against the negative ways in which worldviews and also religions can be used.

The Netherlands is a pluralist society with a secular government. This has helped us over time to develop equal rights for each and every person. The Dutch way of respecting pluralism and secularity allows for the expression of religious diversity, rather than trying to eliminate this from the public sphere. Obviously this has been contested from the beginning and remains so today. That is one reason why our government has appointed a Special Envoy for Religion and Belief, Mr. Jos Douma.

Bringing together diplomats, religious leaders, members of parliament, academic researchers, and leading representatives of NGOs, creates an extraordinary opportunity to reflect on the role of religion in our common search for peace and security.

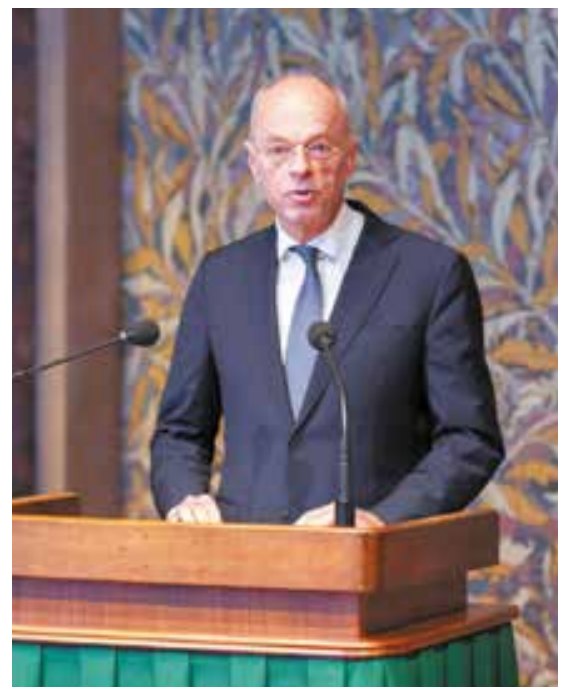

